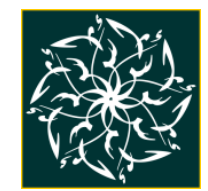

JAS: Jurnal Ilmiah Ahwal Syakhshiyyah

Volume 2 Nomor 1 Tahun 2020

e-ISSN: 2714-7398

\title{
IKHTILAF AL-FUQAHA : \\ STUDI TENTANG AKAR PERBEDAAN PEMIKIRAN HUKUM ISLAM
}

\author{
Khoirul Asfiyak \\ FAI Unisma Malang \\ e-mail: khoirul.asfiyak@unisma.ac.id,
}

Diterima: 06-06-2020 | Direvisi: 15 Juni 2020 | Disetujui: 19 Juni 2020

(C) 2020 Program Studi Ahwal Syakhshiyyah Fakultas Agama Islam Universitas Islam Malang

\begin{abstract}
Abstrak
Sejarah Islam telah mewariskan sebuah peninggalan khasanah intelektual yang teramat berharga, yaitu pemikiran fiqh yang sangat kaya akan sentuhan filosofis dan hikmah kesyariahan. Para ulama telah dengan sangat produktif menuliskan gagasan intelektualnya di seputar pemikiran hukum (legal opinion) pada awal-awal puncak gemilang peradaban Islam abad 2 - 3 Hijriyah. Oleh karena sangat produktifnya para ulama masa itu dalam upaya memahami pesan-pesan Syari' yang termuat dalam al qur'an maupun al-Hadis, imbasnya umat sekarangpun mewarisi pula sejumlah perbedaan pendapat yang dihasilkan dari dialektika hukum Islam yang terjadi kala itu. Sehingga umat merasa inferior untuk bisa bersatu pendapat dalam platform yang sama atau dalam menemukan kalimatun sawa yang mampu mengikis sekecil apapun bentuk dan ragam varian perbedaan pendapat tersebut. Dari titik inilah tulisan ini akan disajikan. Di sisi lain, sejatinya penelitian ini termasuk jenis penelitian metode kajian dengan menggunakan pendekatan penelitian kualitatif yang teknik analisis datanya meminjam teori Analisis Isi. Sehingga persoalan yang menjadi core tulisan ini akan dianalisis berdasarkan prosedur baku yang terdapat dalam teknik Analisis Isi. Kesimpulan akhir dari kajian ini adalah bahwa terdapat beragam akar perbedaan pendapat di antara para ulama itu terutama sekali hal itu disebabkan oleh : Perbedaan pendapat yang diakibatkan oleh eksistensi Nash, Perbedaan pendapat akibat penggunaan qaidah ushuliyah maupun qaidah fiqhiyyah, perbedaan daya intelektualitas masing-masing ulama, dan Perbedaan metode istinbathiyah dalam menginstinbathkan hukum.
\end{abstract}

Kata kunci: Iktilaf Fuqaha, Akar Perbedaan, Hukum Islam.

\begin{abstract}
Islamic history has bequeathed a legacy of intellectual treasures that are extremely valuable, namely fiqh thinking which is very rich in philosophical touches and wisdom of shari'ah. The scholars have been very productive in writing their intellectual ideas around legal opinion (legal opinion) at the
\end{abstract}

This work is licensed under Creative Commons Attribution Non Commercial 4.0 International License Available online on: http://riset.unisma.ac.id/index.php/fai/index 
beginning of the glorious peak of Islamic civilization in the 2nd - 3rd century Hijriyah. Because the scholars were very productive at that time in an effort to understand Shari"s messages contained in the Qur'an and Al-Hadith, the impact of the present day community also inherited a number of differences of opinion resulting from the dialectics of Islamic law that happened at that time. So that people feel inferior to be able to unite opinions in the same platform or in finding sentences that can erode the slightest form and variety of variants of the difference of opinion. From this point this paper will be presented. On the other hand, this research is actually a type of research method of study using a qualitative research approach whose data analysis techniques borrow the theory of Content Analysis. So the issues at the core of this paper will be analyzed based on standard procedures contained in the Content Analysis technique. The final conclusion of this study is that there are various roots of disagreement among the scholars especially because it is caused by: Differences of opinion caused by the existence of Nash, Differences of opinion due to the use of qaidah ushuliyah and qaidah fiqhiyyah, differences in intellectual power of each ulama, and the differences between the istinbathiyah method in instilling the law.

Keywords: Iktilaf Fuqaha, Roots of Difference, Islamic Law.

\section{A. Pendahuluan}

Salah satu warisan intelektual yang ditinggalkan oleh peradaban Islam masa lalu adalah karya gemilang para Fuqaha dan Ushuliyyun dalam bidang Fiqh maupun Ushul Fiqh. Corak fiqh yang berhasil disusun oleh para Juris Muslim itu tidak saja selalu mencoba menjawab terhadap segala persoalan baru yang muncul di hadapan ummat (Fiqh Waqi'iy) namun sebegitu jauh para imam madzhab juga berhasil mengkreasikan beberapa pemikiran hukum (legal opinion) yang bernuansa ke masa depan (Fiqh Nadhariy). Dikatakan bernuansa ke masa depan, karena kadangkala para Juris Muslim itu sudah memprediksi atau meramalkan tentang suatu kejadian yang belum ada bentuk konkritnya di masa kini dan baru akan terjadi pada masa-masa belakangan. Visi hukum seperti ini menjadi prestasi yang mengagumkan dari warisan intelektual peradaban Muslim masa lalu sehingga umat yang hidup pada masa kini mampu mengeruk hikmah yang luar biasa dari peninggalan besar mereka itu.

Sekalipun demikian tidak dapat diingkari bahwa tinggi dan maraknya semangat (ghirah) berijtihad para Imam Madzhab pada masa itu ternyata juga meninggalkan persoalan yang tidak sederhana bagi generasi masa kini. Warisan fiqhiyah yang tersebar luas dalam kitab-kitab fiqh empat madzhab itu sudah

JAS: Volume 2 Nomor 1, 2020 
Ikhtilaf al-Fuqaha :

barang tentu tidak berada dalam satu aras yang sama. Pemikiran hukum yang dihasilkan para Juris Muslim itu juga menyisakan perdebatan dan perbedaan pendapat yang luar biasa sulit untuk didamaikan dalam satu platform yang sama, atau dalam satu kalimatun sawa yang mampu mengakomodir seluruh bentuk perbedaan pendapat yang terjadi. Beberapa perbedaan pendapat itu memang berhasil dikompromikan atau dibuatkan solusi penyelesaian akhirnya, namun tidak sedikit juga perbedaan pendapat para fuqaha itu mengalami jalan buntu (Tawaquf) sehingga pengimplementasian hasil ijtihad imam madzhab itu tergantung tingkat kepercayaan ummat terhadap imam madzhab itu sendiri. Dan tentunya tergantung pada kemauan atau selera madzhab yang dipilih oleh pemerintahan sebuah negara Muslim yang hendak mengkompilasi dan mengkanonisasi pemikiran hukum imam madzhab tersebut.

Cita ideal masyarakat muslim di seluruh dunia adalah terwujudnya satu masyarakat muslim yang bersatu dalam sebuah pemerintahan bersama dengan mempraktekkan satu hukum yang sama yang berlaku bagi semua muslim dimanapun ia berada. Tentu saja ini sekedar utopia yang tidak akan pernah sekalipun berjumpa dengan fakta di dunia nyata. Sehingga dalam kehidupan kesehariannya umat Islam terbiasa dengan tradisi perbedaan pendapat, terbiasa untuk selalu tidak bersatu pendapat dan terbiasa untuk memilih jalan yang berbeda dengan jalan yang diyakini oleh kelompok mayoritas sekalipun. Persoalan ini menjadi menarik karena usia perbedaan pendapat atau ihktilaf fuqaha ini sudah sangat tua, hampir setua usia risalah yang dibawa oleh Rasulullah itu sendiri. Sehingga dalam kajian sederhana ini persalan atau fokus kajiannya berkisar di seputar faktor atau akar penyebab munculnya ikhtilaf al-fuqaha tersebut disertai analisa sederhana untuk memahami fenomena yang terjadi. Alih-alih umat berusaha sekuat tenaga menuju pada kesatuan pendapat, yang terjadi justru umat seringkali mencari pembenaran normatif perbedaan pendapat yang terjadi di kalangan pengikut madzhab bahkan hingga saat sekarang ini. Seolah nash sudah memprediksi dan memberi dasar epistemologi tentang kemunculan ikhtilaf al fuqaha ini sebagai sebuah keniscayaan yang tidak bisa dihindari. Oleh karena itu kajian sederhana ini berusaha untuk mendudukkan persoalan ikhtilaf ini pada posisi yang semestinya sehingga menjadi jelas duduk permasalahannya dan umat bisa mengambil sikap antara meneruskan perbedaan pendapat ini atau mulai merintis untuk meretas jurang perbedaan yang semakin menganga itu.

JAS: Volume 2 Nomor 1, 2020 


\section{B. Metode}

Adapun metode kajian yang digunakan dalam penelitian tentang ikhtilaf al fuqaha ini adalah sebagai berikut: Pendekatan yang diterapkan dalam kajian sederhana ini adalah lebih ke arah pendekatan yang bersifat kualitatif. Sedang Teknik Analisis Datanya menggunakan teknik Analisis isi (content analysis) yakni sebuah teknik yang secara komprehensip berusaha menggali beragam keterangan dari pesan atau informasi yang disajikan dalam wujud lambang atau simbol tertentu yang terdokumentasi atau dapat didokumentasikan.

Sedang sumber data penelitian ini diperoleh dari beragam sumber yang bersifat kekinian dengan tidak meninggalkan referensi klasik yang menjadi masterpiece dalam bidang periwayatan hadis. Di antara karya monumental yang dijadikan sebagai sumber penelitian ini adalah : Syah Waliyullah al Dahlawiy: alInshof Fi Bayan al Ikhtilaf, Yusuf Qardhawiy: il-Ijtihad Fi al-Syariat al-Islamiyah Ma'a Nadhariyatin Tahliliyah Fi al-Ijtihad al-Mu'ashir, Ahmad Hassan: The Early Development of Islamic Yurisprudence, Abdul Wahab al-Kholaf, Khulashoh Tarikh Tasyri' al Islam, Abu Zahrah: Muhadlarah Fi Tarikh al Madzahib al Fiqhiyah.

\section{Pembahasan}

Berdasarkan penelusuran buku referensi yang relevan dengan tema kajian ditemukan beberapa pola penyebab perbedaan pendapat di kalangan ulama itu. masing-masing pemerhati kajian fiqh dan ushul fiqh ini berbeda analisanya dalam menunjuk faktor pemicu ikhtilaf fuqaha itu. Hal ini seperti yang disinggung oleh Syah Waliyullah al-Dahlawiy, Abdul Wahab al Kholaf, Muhammad Ali al Sayis, Thoha Jabir Fayyad al-Ulwani, Ahmad Hasan dll dalam karya beliau masingmasing. Dan untuk lebih menyederhanakan pembahasan maka berikut ini akan dibahas beberapa faktor yang menjadi penyebab munculnya ikhtilaf al-fuqaha menurut kacamata banyak pemerhati sejarah hukum Islam.

\section{Akar Penyebab munculnya Ikhtilaf al-Fuqaha}

\section{a. Perbedaan pendapat yang diakibatkan oleh eksistensi Nash (al Qur'an} dan al Hadis) itu sendiri

Perbedaan itu lebih banyak disebabkan oleh kesulitan para ulama dalam mengimplementasikan bunyi teks wahyu itu terhadap berbagai persoalan yang muncul. Kesulitan itu timbul bisa jadi karena persoalan yang muncul di tengahtengah masyarakat itu, tidak didapatkan secara jelas aturan hukumnya secara baku dan rigid. Oleh karena tidak ditemukannya aturan yang baku dan rigid dari

JAS: Volume 2 Nomor 1, 2020 
Ikhtilaf al-Fuqaha :

Studi tentang Akar Perbedaan Pemikiran Hukum Islam

nash, maka pada gilirannya fuqaha menggunakan ar-ra'yu dalam memberi status hukum persoalan tersebut. Patut diduga bahwa penalaran yang dilakukan oleh jumhur fuqaha itu adakalanya didasarkan pada semangat atau ruh syariat dan adakalanya juga murni berdasarkan pada alur fikir manusia yang dipengaruhi oleh kemauan, hasrat dan kondisi sosial budaya setempat. Artinya ar-ra'yu yang dikedepankan oleh sebagian fuqaha ketika menghadapi persoalan yang tidak diketemukan nash-nya itu, seringkali dasar pijakannya masih dalam bingkai nash, misalnya dari segi masqashid al tasyri'nya, dan bisa jadi dasar pijakannya bukan berupa nash akan tetapi berdasarkan adat istiadat setempat yang bersifat lokal dan partikular. Penggunaan ar-ra'yu pada zaman Nabi SAW tidak begitu dibutuhkan karena Nabi SAW masih hidup sehingga setiap persoalan bisa langsung ditanyakan kepada beliau.

Akan tetapi pemikiran yang bersifat fiqhiyah-ijtihadiyah ini, barulah muncul pada masa-masa belakangan saja, dan nampaknya fenomena ini adalah sebagai akibat terhentinya wahyu ke dalam kehidupan masyarakat waktu itu. Hukum Islam, ijtihad dan perbedaan pendapat barulah nampak secara signifikan pada abad ke 2 hijriah. Lebih ekstrim lagi menurut analisis orientalis barat Joseph Schacht ia berpendapat bahwa hukum Islam belumlah muncul atau eksis pada masa as-Sya'bi (w.110 H). Teori ini kemudian dilanjutkan dengan sebuah pernyataan bahwa apabila diperoleh beberapa tradisi dari Nabi SAW yang berkaitan dengan hukum Islam, maka dapat dipastikan tradisi itu adalah bikinan orang-orang yang lahir sesudah masa as-Sya'bi tersebut. Selanjutnya Schacht berargumen bahwa hukum Islam baru dikenal semenjak masa adanya kebijakan atau preseden khalifah melakukan, padahal khalifah-khalifah sebelumnya tidak pernah mengangkat qadhi. Dan pengangkatan hakim atau qadhi ini baru mentradisi dalam pemerintahan Islam pada era dinasti Ummayah (Schacht, 1964:34). Ini mengindikasikan bahwa pemikiran tentang hukum Islam baru muncul pada masa akhir pemerintahan dinasti Ummayah, sehingga dengan demikian semenjak kehadiran Nabi SAW hingga 100 tahun berikutnya tidak ada pemikiran tentang hukum Islam sama sekali. Pendapat ini ditolak oleh banyak ilmuwan di antaranya adalah : Noel J. Coelson yang menyatakan bahwa "They produced a comprehensive system of rules, largely in opposited to existing legal practice ehich express the religious ideal (mereka telah menghasilkan sistem aturan-aturan (hukum) secara komprehensip yang mengekspressikan nilai-nilai keagamaan yang pada umumnya berbalikan dengan praktek hukum yang terwujud (Azizi, 2002:17-18)

JAS: Volume 2 Nomor 1, 2020 
Sikap dan cara berpegang pada sunnah dan standar yang digunakan untuk menguatkan satu riwayat atau riwayat yang lain adalah salah satu dari sekian faktor penyebab perbedaan pendapat itu. Berpegang pada sunnah itu didasarkan pada keterpercayaan para periwayatnya dan cara-cara periwayatannya. Para imam mujtahid berbeda sikap dan cara mereka dalam menerima sunnah. Para imam mujtahid Iraq, misalnya Abu Hanifah (w.150H/767) dan rekan-rekannya berhujah dengan sunnah mutawatir dan masyhur saja. Mereka memandang kuat sunnah yang diriwayatkan oleh orang-orang yang tsiqah dari kalangan ahli fiqh. Oleh karena itu Abu Yusuf berkata "Wajib atas kamu berpegang pada hadis yang diriwayatkan oleh para jamah ahli hadis dan yang disampaikan oleh para ahli fiqh". Para imam mujtahid Madinah misalnya, Imam Malik (w.179H/798) dan rekanrekannya berpegang pada hadis-hadis yang dipandang kuat oleh ahli fiqh Madinah tanpa diperselisihkan di antara mereka. Dan mereka meninggalkan hadis-hadis Ahad yang bertentangan dengan amalan para ahli fiqh Madinah. Sedangkan imamimam mujtahid lainnya berhujah dengan hadis yang diriwayatkan oleh para periwayat yang adil dan dhabit tanpa melihat apakah mereka dari kalangan ahli fiqh atau bukan dan apakah sesuai dengan amalan ahli Madinah atau bertentangan.

Dalam memahami konteks nash para fuqaha juga mengalami perbedaan pendapat dalam menentukan 'illat hukum terhadap persoalan yang tiada nash hukumnya. Sangatlah sulit untuk menentukan 'illat yang terkandung dalam sebuah nash, untuk kemudian dapat dijadikan sebagai tolok ukur terhadap persoalan yang sama yang tidak memiliki ketentuan hukumnya. Perbedaan antara 'illat hukum dengan hikmah hukum sangat tipis,. kesalahan menetapkan 'illat sudah barang tentu akan berakibat pada perbedaan hasil ijtihad. Hal lain yang berkaitan dengan eksistensi nash dan yang banyak menimbulkan perbedaan pendapat adalah adanya konsep pembagian sumber hukum Islam yang biasa dikenal dengan istilah Qathiyyul / Dhanniyul Tsubut dan Qathiyyul / Dhaniyyul Dalalah. Pada dasarnya ajaran Islam dapat dibagi menjadi dua kelompok, yakni :

pertama, ajaran Islam yang bersifat absolut, universal dan permanen, tidak berubah-ubah dan tidak dapat diubah, termasuk dalam kelompok ini adalah ajaran Islam yang tercantum dalam al-Qur'an dan al-hadis mutawatir yang penunjukkannya telah jelas (Qathiy al-Dalalah).

kedua, ajaran Islam yang bersifat relatif, tidak universal dan tidak permanen, melainkan dapat berubah dan diubah, termasuk dalam kelompok kedua ini adalah ajaran Islam yang dihasilkan melalui proses ijtihad. Kerangka berfikir seperti ini sering muncul di kalangan ahli ushul fiqh dan pakar pembaharuan dalam hukum

JAS: Volume 2 Nomor 1, 2020 
Islam. Di kalangan ahli ushul fiqh dikenal dikotomi antara dalil qathi dan dalil dhanniy baik eksisitensi (tsubut) maupun penunjukannya (dalalah).

Keberadaan hadis sebagai sumber hukum Islam seringkali dipermasalahkan, hanya hadis yang sampai pada peringkat mutawatir sajalah yang eksistensinya sama dengan al Qur'an. Sedangkan al-hadis yang di bawah peringkat mutawatir termasuk kelompok dhanniyul tsubut yang masih dipertanyakan keberadaannya. Jumlah hadis yang termasuk kelompok terakhir ini jauh lebih banyak bila dibandingkan dengan hadis yang masuk dalam kelompok mutawatir. Adapun dari segi penunjukannya (Dalalahnya) adakalanya tegas (Qathiy) adakalanya tidak tegas (Dhanniy). Terhadap hadis yang dhanniy al-tsubut dan dhzanniy al-dalalah inilah para fuqaha banyak mengistinbathkan hukum. Oleh karena bersumber dari dalil yang dhanniy maka sudah dapat diduga bahwa kesimpulan hukum yang dihasilkannyapun bersifat dhanniy pula. Dalam rumus aksioma yang sederhana dapat dinyatakan bahwa jika ayat atau hadis (nash)-nya berstatus dhanniy ditambah dengan penggunaan nalar yang bersifat dhanniy pula (karena perbedaan kecerdasan) maka kesimpulan yang dihasilkannya adalah pendapat yang berbeda-beda. Sebaliknya jika terdapat ayat atau hadis yang qathiy kemudian dikaji dengan daya kecerdasan yang sama maka akan menghasilkan persamaan atau kesesuaian pendapat.

\section{b. Perbedaan pendapat akibat penggunaan qaidah ushuliyah maupun qaidah fiqhiyyah}

Sebab-sebab ikhtilaf yang berkaitan dengan kaidah-kaidah ushuliyah itu di antaranya adalah persoalan di sekitar an-Naskh, yakni apakah nasakh itu benarbenar ada dalam al-Qur'an ataukah ia hanya dugaan atau tafsiran ulama atas beberapa ayat dalam al-Qur'an. Bagaimana dan kapan munculnya ide nasakh (Pembatalan ayat-ayat al Qur'an) tertentu dalam sejarah Islam yang awal tidaklah mudah ditemukan. Akan tetapi nampaknya paling mungkin bahwa ketika para ahli tafsir dan ahli hukum tidak dapat mendamaikan ayat-ayat yang secara dhahir nampak saling bertentangan mereka lalu mengemukakan teori ini. Mereka menganggap bahwa ayat-ayat berikut ini mendukung teori nasakh :

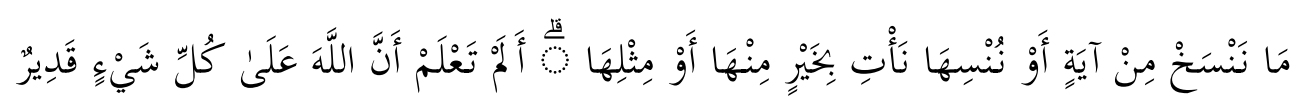

"Ayat mana saja yang Kami nasakhkan, atau Kami jadikan (manusia) lupa kepadanya, Kami datangkan yang lebih baik daripadanya atau yang sebanding 
Khoirul Asfiyak

dengannya. Tidakkah kamu mengetahui bahwa sesungguhnya Allah Maha Kuasa atas segala sesuatu"(Q.S al Baqarah :106)

Berdasarkan ayat-ayat tersebut para ulama ahli tafsir maupun ahli ushul berkeyakinan bahwa terdapat beberapa ayat dalam al-Qur'an yang telah dihapus. Berdasarkan konsep inilah kemudian Mu'tazilah semakin mengukuhkan pendapatnya bahwa al-Qur'an adalah mahluq, karena ternyata ia bisa dihapus dan dibatalkan. Mereka berargumentasi dengan dalih jika al-Qur'an memang bisa dibatalkan maka tidak mungkin ia bersifat abadi akan tetapi satu kelompok dari mereka dikabarkan menolak teori pembatalan ini. Mereka menganggap tidak ada satu ayatpun dari al Qur'an yang telah dibatalkan.

Teori klasik nasakh tidak mungkin berasal dari Nabi SAW karena tidak diketemukan informasi apapun dari beliau akan adanya ayat-ayat yang dibatalkan dalam al-Qur'an dengan pengertian ini. Seandainya satu ayat benar-benar telah dibatalkan, tentu beliau akan menunjukkannya dengan tegas kepada orang banyak, karena ajaran al-Qur'an ditujukan bagi setiap zaman dan tempat. Sehingga sangat sulit dipercaya bahwa rasulullah telah menyerahkan persoalan yang demikian penting yang menyangkut pemahaman al Qur'an pada kebijaksanaan orang banyak. Lebih jauh di antara para sahabat dikabarkan juga telah berbeda pendapat di kalangan mereka sendiri tentang ide konsep pembatalan al-Qur'an itu (Hassan, 1994:62)

Bahkan telah menjadi kecenderungan bagi para sarjana muslim untuk menekan jumlah ayat-ayat yang dibatalkan karena ia telah mencapai suatu jumlah yang sangat mengherankan. Ayat-ayat yang dikatakan sebagai telah dibatalkan itu dijumlahkan sebagai berikut:

1. ayat-ayat individual yang dibatalkan

201 ayat

2. ayat-ayat yang dibatalkan dari surat al-Ahzab

213 ayat

3. surat yang dibatalkan seluruhnya yang ada pada surat ke- $9 \quad 130$ ayat

4. dua surat yang dibatalkan bersama-sama dikenal sebagai al-Khala wal-Khafd

18 ayat

5. dua ayat mengenai penyusuan seorang anak dan hukum rajam bagi pezina

Total ;

564 ayat

Di antara penulis-penulis modern yang tertarik mengenai masalah ini seperti Muhammad Abduh menerima teori nasakh itu sendiri, akan tetapi secara praktis menolak pembatalan ayat-ayat al-Qur'an. Dalam semua kasus demikan ia

JAS: Volume 2 Nomor 1, 2020 
berusaha untuk menyelaraskan ayat yang disebut sebagai ayat-ayat yang bertolak belakang (ayat-ayat Ta'arudh). Penulis-penulis lainnya bahkan selangkah lebih maju dan menolak sepenuhnya teori nasakh ini. Sir Sayyid Ahmad Khan dengan tegas menolaknya. Menurut beliau kata nasakh dalam al-Qur'an surat al-Baqarah ayat 106 berarti pembatalan undang-undang hukum yang diwahyukan pada nabinabi sebelum nabi Muhammad SAW. Muhammad al Khudhari Beik dengan cara yang lebih masuk akal dan rasional menyelaraskan semua ayat dianggap imam al Suyuthi sebagai telah dibatalkan (Hassan, 1994:64)

Jika ayat 106 dari surat al-Baqarah dibaca berdasarkan konteks yang mengitarinya tak diragukan lagi bahwa ayat tersebut berbicara mengenai penghapusan hukum yang diwahyukan kepada rasul-rasul bani Israil. Separuh bagian pertama surat al-Baqarah dimana ayat 106 tersebut turun, berisi tentang perbantahan al-Qur'an dengan kaum yahudi yang akhirnya berpuncak pada perintah untuk merubah qiblat umat Islam dari Yurusalem ke Ka'bah di Makkah, yang menandakan pemutusan hubungan sepenuhnya dengan hukum yahudi yang telah dibatalkan itu. Nampaknya para ulama terkecoh dengan lafadz "ayat" yang terdapat dalam surat al-Baqarah tersebut. Akan tetapi sesungguhnya dalam beberapa pandangan ulama lain lafadz "ayat" itu dalam surat al-Baqarah bukan berarti "sebuah ayat yang merupakan bagian dari sebuah surat al-Qur'an". Secara harfiyah "ayat" berarti tanda, bukti atau ciri yang dengannya seseorang atau sesuatu dapat dikenali dan sinonim dengan "alamah" secara tersirat pula ini juga berarti "pesan" atau "komunikasi" yang dikirim dari seseorang atau kelompok kepada yang lain". Dan dalam hal ini sinonim pula dengan 'ar-risalah". Dari sini terambil arti sekunder yakni ayat dalam al-Qur'an atau lebih ketat lagi "satu bagian al-Quran sehabis mana pembacaan boleh dihentikan". al-Qur'an sendiri mempergunakan dengan arti "Tanda dari Tuhan" "Mu'jizatNya" "Peraturan-Nya" Pesan-Nya" "Wahyu-Nya" sehingga membatasi konotasinya hanya pada arti sekundernya yang sama sekali tidak sesuai dengan konteksnya nampaknya merupakan tindakan yang perlu untuk dikaji kembali.

Masih berkaitan dengan teori Naskh jumhur ulama Hanafiyah berpendapat bahwa tambahan ketentuan terhadap nash yang sudah ada sebelumnya berarti menunjukkan dihapuskannya nash yang pertama itu. Di kalangan mereka dikenal qaidah: الزيادة على النص يفيد النشح (tambahan hukum terhadap ketentuan hukum yang sudah ada berarti naskh) Oleh karena itu menurut golongan Hanafiyah ayat yang menjelaskan tentang had hukuman bagi pezina wanita dan pezina laki-laki

JAS: Volume 2 Nomor 1, 2020 
Khoirul Asfiyak

yang didera sebanyak 100x berdasarkan surat an Nuur : 2 dibatalkan ketentuan hukumnya karena adanya sebuah hadis yang berbunyi :

$$
\text { البكر بالبكر جلد مائة ونفى سنة والثيب بالثيب جلد مائة والرجم (رواه المسلم) }
$$

"Pezina perjaka yang berzina dengan seorang gadis, didera sebanyak $100 \mathrm{x}$ dan kurungan penjara selama satu tahun, sedang pezina laki-laki dan perempuan yang pernah kawin di dera 100x dan dirajam"

Berbeda dengan jumhur ulama baik dari golongan Syafi'iyah, Malikiyah maupun Hanbaliyah mereka berpendapat bahwa tambahan hukum terhadap nash yang sudah ada, tidak berdampak terhadap penghapusan nash yang pertama. Akan tetapi berfungsi sebagai penjelas belaka.

Demikian juga para ulama berbeda pendapat dalam memegangi kedudukan istisna' , apakah istisna' yang terdapat sesudah beberapa jumlah yang di'athafkan satu sama lainnya kembali kepada semuanya ataukah ia hanya kembali kepada jumlah terakhirnya saja. Jumhur fuqaha berpendapat bahwa istisna' itu kembali kepada keseluruhannya sedangkan menurut Abu Hanifah istisna' itu hanya kembali kepada jumlah terakhir saja. Sebagai contoh terdapat sebuah ayat yang berbunyi sebagai berikut :

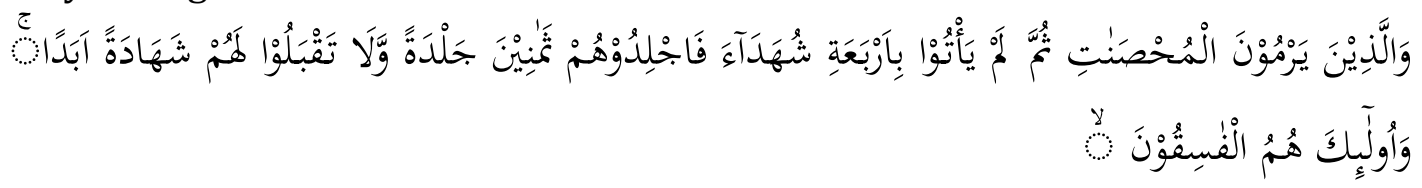

"Dan orang-orang yang menuduh wanita yang baik-baik (berbuat zina) dan mereka tidak mendatangkan empat orang saksi, maka deralah mereka (yang menuduh itu) delapan puluh kali dera dan janganlah kamu terima kesaksian mereka buat selamalamanya dan mereka itulah orang-orang yang fasik (Q.S an Nur : 4)

dari ayat tersebut di atas dapat disimpulkan bahwa hukuman bagi orang yang menuduh zina tanpa bisa membuktikannya dengan empat orang saksi adalah sebagai berikut :

a. Dera delapan puluh kali

b. Dicabut haknya untuk menjadi saksi dalam kasus apapun

c. Orang itu dinyatakan fasik

kemudian datang 'istisna' bagi orang-orang yang bertaubat yaitu pada ayat berikutnya:

JAS: Volume 2 Nomor 1, 2020 
Ikhtilaf al-Fuqaha :

Studi tentang Akar Perbedaan Pemikiran Hukum Islam

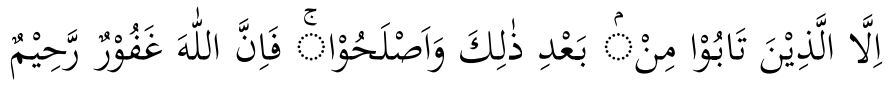

"Kecuali orang-orang yang bertaubat sesudah itu dan memperbaiki dirinya maka sesungguhnya Allah Maha pengampun lagi Maha Penyayang (Q.S an-Nur :25)

Bagi yang berpendapat bahwa istisna' itu kembali kepada jumlah terakhir saja maka bila orang itu telah bertaubat, tidak lagi dinyatakan fasiq dan tetap harus dikenakan dera serta belum bisa dijadikan saksi. Adapun pendapat yang kedua, menyatakan bahwa istisna' kembali kepada semuanya, maka orang yang sudah bertaubat itu tidak lagi dinyatakan fasiq dan juga dikembalikan haknya untuk menjadi saksi, akan tetapi tetap dihukum dera karena hukuman dera itu menyangkut hak 'adamiy yang tidak bisa digugurkan dengan taubat. Dengan demikian jelas sekali dapat dipahami bahwa penggunaan metode ushuliyyah yang berbeda sudut pandangnya akan berakibat perbedaan dalam kesimpulan hukum. Seperti juga ketika kelompok Syafi'iyah berbeda pendapat dengan golongan Hanafiyah dalam rangka memahami hukum terhadap segala sesuatu yang tidak ditentukan status hukumnya, apakah sesuatu itu hukumnya halal ataukah haram? Mazhab Imam Syafi'i berdasarkan kaidah :

$$
\text { الأصل فن الأشياء الإباحة حتى يدل الدليل على التحريم }
$$

Sedangkan menurut madzhab Hanafiyah qaidah yang berlaku adalah :

$$
\text { الأصل فن الأشياء للتحريم حتى يدل الدليل على الإباحة }
$$

Jadi menurut madzhab Syafi'iyah asal hukum sesuatu itu adalah dibolehkannya manusia untuk mengerjakan dan memakan atau menggunakannya sampai ada dalil yang mengharamkannya. Hal ini atas dasaar dalil dalam al-Qur'an surat alBaqarah ayat 29 yang berbunyi :

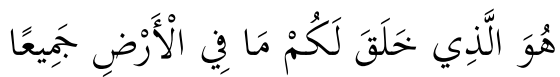

Juga berdasarkan hadis berikut :

$$
\begin{aligned}
& \text { عن ابى درداء قال :قال رسول الله صلى الله عليه و سلم : ما احل الله فهو حلال وما حرم فهو حرام وما } \\
& \text { سكت عنه فهو عفو فاقبلوا من الله عافيته فإن الله لم يكن ينسى شيء(رواه الطبران) }
\end{aligned}
$$

catatan hadis ini diriwayatkan oleh banyak muhadisin namun sanadnya atau kualitas hadisnya masih banyak diperselisihkan para ulama.

Sedangkan madzhab Abu Hanifah berpendapat bahwa asal hukum sesuatu itu adalah haram sehingga ada dalil yang membolehkannya, kebalikan dari JAS: Volume 2 Nomor 1, 2020 
Khoirul Asfiyak

pendapat madzhab Imam Syafi'i bahwa asal segala sesuatu adalah boleh sehingga ada dalil yang mengharamkannya. Hal yang demikian ini dapat menimbulkan perbedaan pendapat di kalangan ulama dalam menetapkan hukum terhadap suatu persoalan yang belum diketahui keterangannya dalam nash.

\section{c. Perbedaan daya intelektualitas masing-masing ulama}

Menafikan perbedaan tingkat kecerdasan ulama dalam memahami aspekaspek yang menyebabkan perbedaan pendapat bukanlah suatu sikap yang bijaksana dan dewasa. Metode yang ditempuh dan dijalani oleh akal untuk mengkaji suatu obyek pengetahuan bersifat relative dan terbatas. Terbatas oleh kemampuan akalnya itu sendiri, terbatas juga oleh hambatan-hambatan (Idols) yang seringkali mengungkung kebebasan dan kemurnian corak pemikirannya. Di dalam kitab ushul fiqh secara panjang lebar banyak ditulis tentang kondisi-kondisi inherent manusia yang mengakibatkan seseorang mukallaf tidak bisa menjalankan hukum azimah yang telah ditetapkan oleh Allah. Halangan-halangan itu biasanya disebut sebagai Awarid al-Ahliyah. Kenyataan itu membuktikan bahwa manusia lahir sembari membawa keterbatassan-keterbatasan yang menghalangi dirinya untuk secara lebih jauh mengenali dan memahami semua fenomena yang terjadi di dunia ini. Salah satu dari Awarid al-Ahliyah itu adalah sifat lupa. Tidak dapat dipungkiri hampir semua manusia telah merasakan yang namanya lupa tidak terkecuali ilmuwan, perawi ataupun ulama sekalipun yang tidak dihinggapi penyakit lupa ini. Bisa jadi daya ingat seseorang akan mengalami penyusutan penyusutan atau kekurangan disana-sini mengingat usia yang sudah udzur.

\section{d. Perbedaan metode istinbathiyah dalam menginstinbathkan hukum}

Di antara keempat madzhab yakni Hanafi, Maliki, Syafi'I dan Hanbali terdapat perbedaan yang cukup fundamental dalam cara beliau-beliau itu ketika mengistinbathkan hukum dari dalil-dalil syar'iy. Hanafi lebih mengandalkan penggunaan ra'yu di ketika al-Qur'an dan al Hadis tidak membahas suatu persoalan tertentu yang menucul di tengah-tengah masyarakat. Sehingga sangat terkenal di kalangan ulama bahwa madzhab Hanafi banyak memproduksi furu'. Hal ini disebabkan penggunaan qiyas dan ra'yu yang sangat intens di kalangan madzhab Abu Hanifah. Sementara madzhab imam Maliki tidak terlalu mengandalkan penalaran ra'yu sebagai basis istinbath hukum yang mereka lakukan. Nampaknya warisan tradisi Nabi SAW yang melimpah ruah di Madinah menjadi alasan utama keengganan Imam Malik dalam membuat kesimpulan

JAS: Volume 2 Nomor 1, 2020 
Ikhtilaf al-Fuqaha :

Studi tentang Akar Perbedaan Pemikiran Hukum Islam

hukum. Sementara imam Syafii menggunakan hadis Nabi dan tidak alergi terhadap penggunaan ra'yu. Mengingat beliau punya guru baik dari kalangan ahli hadis yakni Imam Malik dan dari kalangan ahli Ra'yu yakni Hasan al Syaibaniy. Adapun Ahmad bin hanbal sebagai penggagas madzhab Hanbaliy juga tidak terlalu mengandalkan ra'yu dalam metode istinbath yang mereka lakukan. Agaknya beliau lebih berkonsentrasi pada pengkajian terhadap hadis-hadis Nabi SAW.

Dengan demikian dapat disimpulkan pendapat di antara mereka salah satunya adalah perbedaan fuqaha dalam metodologi ushul fiqh. Imam Hanafi dan Imam Malik sangat antusias dalam memahami hukum berdasarkan pendekatan istihsan, sementara Imam Syafi'i agak menjauh dari praktek semacam itu. Sekalipun dalam banyak hal hukum yang disimpulkan Imam Syafi'i lewat metode istishlah sebenarnya wujud lain dari istihsan itu sendiri. Demikian juga kelompok Syi'ah enggan untuk menggunakan qiyas sebagai dasar hukum, sehingga mereka mendapat gelar Nufatul Qiyas, dari jumhur ushuliyyun akibat sikapnya itu. Tapi yang jelas perbedaan metodologi itu menjadi factor yang signifikan bagi perbedaan pendapat di kalangan fuqaha.

\section{e. Perbedaan penguasaan / koleksi hadis shahih antar fuqaha}

Beberapa pemerhati / pengkaji hukum Islam memandang bahwa salah satu dari faktor yang menyebabkan perbedaan pendapat di antara para ahli hukum itu adalah karena belum dikodifikasikannya atau belum dikompilasikannya dan belum diverifikasi secara resmi hadis-hadis yang beredar di tengah-tengah masyarakat. Artinya ketika pemikiran fiqh mencapai puncak kematangannya ketika bermunculan mujtahid-mujtahid mustaqil pada abad 2-3 H ternyata hadis Nabi sebagian besar belum sampai ke tangan para fuqaha itu atau jikapun sudah sampai, jumlah hadis yang mereka miliki berbeda-beda atau belum terdeteksinya mana hadis Hadis Nabi SAW yang shahih dan mana yang dhaif. Hal ini disebabkan imam-imam madzhab itu meninggal sebelum sempat membaca kitab hadis bukhari atau juga kitab shahih Muslim yang memang khusus mentakhrijkan hadis-hadis yang berstatus shahih saja. Andaikata imam-imam madzhab itu sempat membacca kitab shahih Bukhari atau shahih Muslim, mungkin perbedaan pendapat itu bisa diminimalisir atau bahkan justru mereka bersatu pendapat dan berhujjah hanya dengan hadis shahih tersebut dan tidak aada satu ulamapun yang berhujjah dengan menggunakan hadis yang berstatus dhaif. Oleh karena itu jika ternyata ada ulama yang dalam pemikiran fiqhiyahnya menggunakan hadis dhaif berarti ulama tersebut tidak mengetahui kala terdapat hadis lain yang lebih shahih.

JAS: Volume 2 Nomor 1, 2020 
Pandangan seperti ini menurut hemat penulis adalah kurang tepat mengingat hal-hal di bawah ini: pertama, sesungguhnya hadis-hadis yang dikemukakan para ulama di dalam kitab-kitab mereka bukan merupakan dalil yang menjadi pegangan imam madzhab tersebut. Memang seringkali mereka sepakat mengenai riwayat yang dikemukakan sebagai dalil oleh seorang imam madzhab, namun kesepatakan itu tidak berarti bahwa semua yang diriwayatkannya merupakan dalil yang dipilih oleh imam tersebut. Jadi, hukum fiqh yang mereka sebutkan adalah hukum dari para imam tersebut, akan tetapi seringkali dalil-dalil yang mereka kemukakan bukanlah dalil bagi hukum-hukum itu. Karena ia sesungguhnya hanyalah hadis yang ditemukan oleh si penyusun kitab yang kebetulan cocok dengan ketetapan yang dibuat oleh imamnya, lalu ia mencantumkannya sebagai dalil bagi ketetapan itu. Sementara sang imam itu sendiri memiliki dalil lain bagi hukum-hukumnya.

Hal seperti ini seringkali terjadi pada madzhab Hanafiyah, karena Imam Abu Hanifah tidak membukukan sendiri pemikiran hukumnya begitu juga dengan dalil-dalil yang digunakan olehnya. Termasuk pula halnya yang terjadi dengan Imam Malik dan Imam Ahmad ibn Hanbal. Imam Syafi'ipun tidak menulis di dalam kitab al Umm-nya kecuali sedikit tentang fiqh dan dalil-dalilnya, maka hadis-hadis yang ditemukan dalam kitab al-Hidayah karya al-Marghinaniy al Hanafiy, al Muhadzdzab karya al-Syairaziy al Syafi'i, kitab ar Risalah karya Ibn Abi Zaid al Qairuwaniy al Malikiy, kitab al Mughniy karya ibn Qudamah al Hanbaliy dan kitab kitab lainnya sebagian besar hadis-hadisnya bukanlah dalil-dalil yang dikemukakn oleh imam madzhabnya sendiri.

Kedua, kadangkala seorang ahli fiqh mengemukakan sebuah dalil dan ia menjadi dalil Imam Madzhab itu sendiri. Kemudian seorang ahli hadis mengeluarkan hadis itu dari kitab-kitab para ahli hadis kontemporer dengan sanad dari para imam madzhab fiqh, seperti keempat kitab sunan yang ada, beberapa kitab musnad, kitab-kitab mu'jam dan lain-lainnya lalu ahli hadis ini menyatakan hadis dari jalur mereka itu sebagai hadis dhaif, maudhu dan sebagainya. Sehingga hadis tersebut tidak bisa dijadikan hujjah. Padahal hadis tersebut diriwayatkan oleh imam mujtahid itu dengan jalurnya sendiri dengan sanad yang sahih dan bisa dijadikan hujjah. Sebagai contoh dalam beberapa kitab yang ditulis oleh para ulama, mereka seringkali meriwayatkan hadis berikut :

$$
\text { ادرعوا الحدود بالشبهات }
$$

(Hindarilah pelaksanaan hukuman jika terdapat hal-hal yang meragukan)

JAS: Volume 2 Nomor 1, 2020 
Ikhtilaf al-Fuqaha :

Seorang ulama yakni al Marghinaniy dalam kitab al-Hidayah jilid IV halaman 139 dengan syarah Fath al Qadir ,mengatakan bahwa hadis tersebut marfu'. Kemudian hadis tersebut ditakhrijkan oleh al Zaila'iy di dalam kitab Nashb al Rayah jilid III halaman 333, bahwa hadis itu Mauquf karena ia merupakan ucapan Sayyiduna Umar. Di dalam sanadnya terdapat Ibn Abi Farwah dan dia adalah matruk dan berasal dari ucapan al Zuhri seorang Tabi'in yang ucapannya tidak dapat dijadikan hujjah. Oleh karena itu Ibn Hazm tidak menganggap hadis itu berstatus marfu' dan beliau membantah al Marghinaniy dalam kitabnya al Muhalla dan membantah para fuqaha yang mengambil pendapat tersebut.

Namun pendapat ibn Hazm ini ditolak oleh al Kamal ibn Hummam dalam kitab Fath al Qadir dan dia menguatkan makna hadis tersebut dengan hadis-hadis dari dua kitab hadis shahih, yakni Bukhari dan Muslim. Beliau berkata "dalam meneliti hadis-hadis yang diriwayatkan dari Nabi SAW atau shahabat ada sesuatu yang pasti dalam permasalahan tersebut. Kita telah mengetahui bahwa Nabi SAW bertanya kepada Ma'iz :"Barangkali engkau baru cium-cium saja atau barangkali engkau meraba-raba saja atau engkau bercumbu rayu saja?" semua interogasi Nabi SAW terhadap Ma'iz itu bernada menggiring dengan memancing supaya Ma'iz menjawab: iya, "saya melakukannya" dan setelah pengakuan Ma'iz terhadap perbuatan zinanya itu. Sehingga Ma'iz terhindar dari tuduhan zina. Apa artinya interogasi atau pertanyaan Rasulullah SAW itu kepada Ma'iz jika tidak mempunyai maksud demikian.

Hal seperti ini tidak beliau lakukan terhadap orang yang mengaku punya utang dengan mengatakan :"barangkali engkau hanya dititipi barang kemudian barang tersebut hilang?" dan seterusnya. dan kesimpulan dari semua ini hukuman boleh tetap dilaksanakan tanpa meragukannya. Makna ini menjadi jelas bila dilihat dari segi hukum syari'at. Adapun keragu-raguan itu adalah keragu-raguan yang sifatnya darurat. Ini adalah bukti yang bagus dan berguna yang bisa memastikan hadis itu berasal dari jalan yang marfu' dan sahih.

Hadis ادرعوا الحدود بالثبهات ini diriwayatkan oleh Abu Hanifah dalam kitab musnadnya yaitu hadis keempat pada bagian kitab 'al-Hudud' halaman 32 cetakan Syirkah al-Mathbu'ah al-'Ilmiyah dan halaman 57 dari kitab Tansiq al Nidham syarah Musnad al Imam karya al-'Allamah aal-Sanbahiliy terbitan karaci Pakistan. ادرعوا sanadnya dari Miqsam dari Ibn Abbas berkata bahwa Rasulullah bersabda الحدود بالثبهات, Miqsam adalah Tsiqah, dinilai tsiqah oleh Ahmad ibn Shalih alMishri imam pada zamannya di Mesir. Juga dinilai tsiqah oleh al-'Ijilliy Ya’ub ibn Sufyan al Daruqutniy. Dari sini dapat diketahui bahwa para imam itu memiliki JAS: Volume 2 Nomor 1, 2020 
Khoirul Asfiyak

sanad tersendiri, juga dapat dipahami keharusan melakukan takhrij hadis-hadis pada fiqh mereka dari kitab-kitab mereka sendiri, bila hal itu mudah dilakukan. Jika sulit maka bisa juga ditahrikan dari kitba-kitab para ahli hadis kontemporer dengan syarat takhrijnya tidak dijadikan ketetapan dan indikator kelemahan madzhab mereka.

Ketiga, terkadang dalil dari para imam fiqh memang betul lemah sanadnya, baik dari jalan mereka sendiri, maupun dari jalan yang telah diketahui oleh para ahli hadis. Akan tetapi dalil ulama fiqh mempunyai penguat yang tidak terhitung banyaknya baik dari al qur'an maupun dari al Sunnah atau dari kedua-duanya sekaligus. Ilustrasi atau deskripsi untuk pernyataan ini adalah adanya sebuah hadis yang berkenaan dengan hak talak yang sebagian besar ulama berpendapat bahwa hak talak itu ada ditangan laki-laki karena ia yang memberi mahar kepada istrinya. Berdasarkan hadis berikut ini :

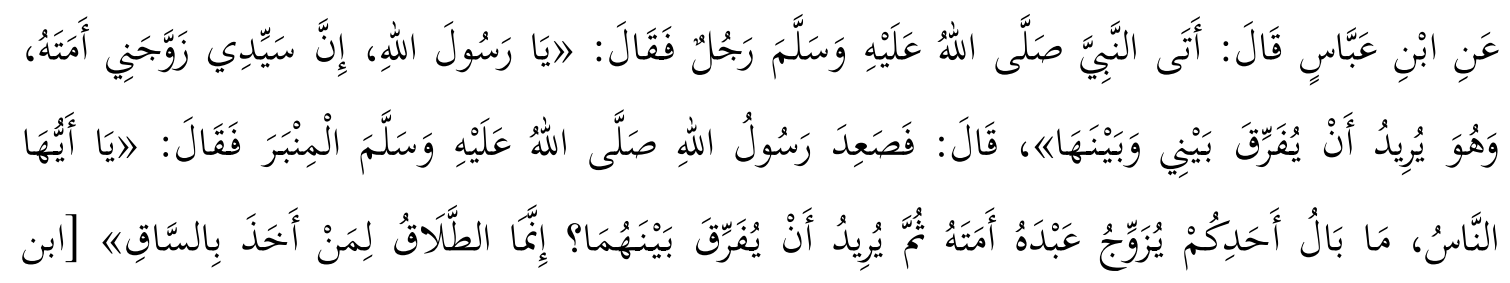

ماجه (Y)

Hadis ini diriwayatkan oleh Ibn Majah jilid 1 halaman 672 dari jalur Yahya ibn Bakir dari ibn Lahi'ah. Ibn lahi'ah adalah dhaif karena kacau ingatannya. Dan hadis ini diriwayatkan juga oleh imam selain ibn Majah dan semuanya tidak terlepas dari pembicaraan para ulama (perdebatan tentang derajat keterterimaan si perawi) . Dan puncak pembicaraan tentang hadis ini adalah pendapat dari alSyaukaniy dalam kitab Nail al-Author jilid VI halaman 254 beliau mengatakan bahwa sanadnya saling menguatkan satu sama lain jika ada yang menilai hadis tersebut hasan, maka penilaian itu atas dasar hal ini.

\section{Simpulan}

Berdasarkan paparan data yang telah disampaikan dalam bab pembahasan sebelumnya maka dapat disimpulkan bahwa fenomena ikhtilaf fuqaha atau perbedaan pendapat di kalangan imam madzhab adalah sebuah fenomena yang kerap terjadi dalam sejarah dan peradaban masyarakat muslim. Perbedaan

JAS: Volume 2 Nomor 1, 2020 
pendapat itu secara natural atau secara sunnatullah adalah bersifat wajar dan normal terjadi dalam kehidupan manusia. Dan secara lebih spesifik dapat dicabarkan di kesimpulan ini bahwa terdapat beberapa faktor yang melatarbelakangi munculnya perbedaan pendapat itu, di antaranya adalah : pertama, perbedaan pendapat yang diakibatkan oleh eksistensi Nash (al Qur'an dan al Hadis) itu sendiri, kedua, perbedaan pendapat akibat penggunaan qaidah ushuliyah maupun qaidah fiqhiyyah, ketiga, perbedaan daya intelektualitas masing-masing ulama, keempat, perbedaan metode istinbathiyah dalam menginstinbathkan hukum, kelima, perbedaan penguasaan / koleksi hadis shahih antar fuqaha. Demikian tulisan sederhana ini disusun tentu saja masih ditemukan banyak kekurangan dalam penyajian data dan penggunaan bahasa, teknis analisisnya dan sebagainya, oleh karena itu sumbangsih kritik dan saran dari pembaca budiman sangat penulis nantikan.

\section{Daftar Rujukan}

Azizi, Qodri, Hukum Islam Kompetisi antara Hukum Islam dan Hukum Umum, Yogyakarta : Gama Media, 2002

Dahlawiy, Syah Waliyullah al-, al-Inshof Fi Bayan Asbaab al Ikhtilaf, Abdul Wafid Nafis (Penerjemah) Jakarta : PT Arista Brahmatasya, 1996

Hassan, Ahmad., The Early Development Of Islamic Yurisprudence, Agah Garnadi (penerjemah) Jakarta : Penerbit Pustaka, 1994

Joseph Schacht, An Introductions to Islamic Law, Clarendom Press, Oxford, 1964

Khalaf, Abdul Wahab al-, Khulashoh Tarikh Tasyri' al-Islam, Wajidi S. (Penerjemah) Jakarta : Raja Grafindo Persada, 2001

Qardhawiy, Yusuf, al-Ijtihad Fi al-Syariah al-Islamiyah Ma'a Nazhariyatin Tahliliyah Fi al-Ijtihad al-Mu'ashir, Kuwait : dar al-Qalam, 198

Sayis, Syaikh M. Ali as-, Tarikh al-Fiqh al Islamiy, Dedi Junaedi (Penerjemah) Jakarta : Akademika Pressindo, 1996

Ya'qub, Ali Musthofa, Kritik Hadis, Jakarta: Pustaka Firdaus, 1995

Zahrah, Abu, Muhadharah Fi Tarikh al-Madzahib al-Fiqhiyah, Kairo : Mathba'ah alMadaniy, $\mathrm{Tt}$

JAS: Volume 2 Nomor 1, 2020 